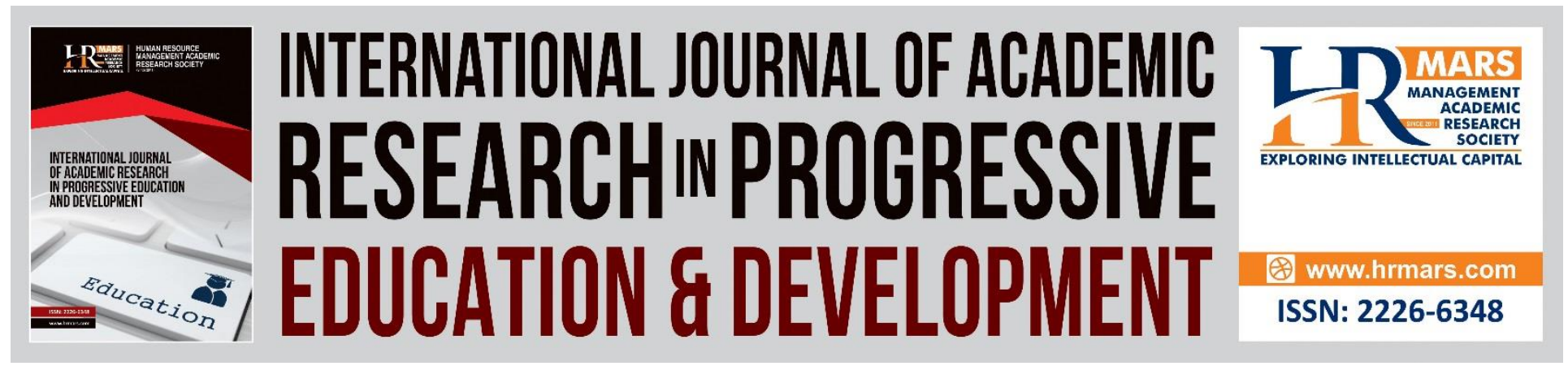

\title{
Teachers and Students Acceptance of an ESL Virtual Teaching-And-Learning in a Secondary School in Seremban
}

Wan Hasnizar Wan Hassan, Harwati Hashim

To Link this Article: http://dx.doi.org/10.6007/IJARPED/v10-i2/8866

DOI:10.6007/IJARPED/v10-i2/8866

Received: 11 February 2021, Revised: 13 March 2021, Accepted: 10 April 2021

Published Online: 29 April 2021

In-Text Citation: (Hassan \& Hashim, 2021)

To Cite this Article: Hassan, W. H. W., \& Hashim, H. (2021). Teachers and Students Acceptance of an ESL Virtual Teaching-And-Learning in a Secondary School in Seremban. International Journal of Academic Research in Progressive Education and Development, 10(2), 435-453.

Copyright: (C) 2021 The Author(s)

Published by Human Resource Management Academic Research Society (www.hrmars.com)

This article is published under the Creative Commons Attribution (CC BY 4.0) license. Anyone may reproduce, distribute, translate and create derivative works of this article (for both commercial and non-commercial purposes), subject to full attribution to the original publication and authors. The full terms of this license may be seen at: http://creativecommons.org/licences/by/4.0/legalcode

Vol. 10(2) 2021, Pg. 435 - 453

http://hrmars.com/index.php/pages/detail/IJARPED

JOURNAL HOMEPAGE

Full Terms \& Conditions of access and use can be found at http://hrmars.com/index.php/pages/detail/publication-ethics 


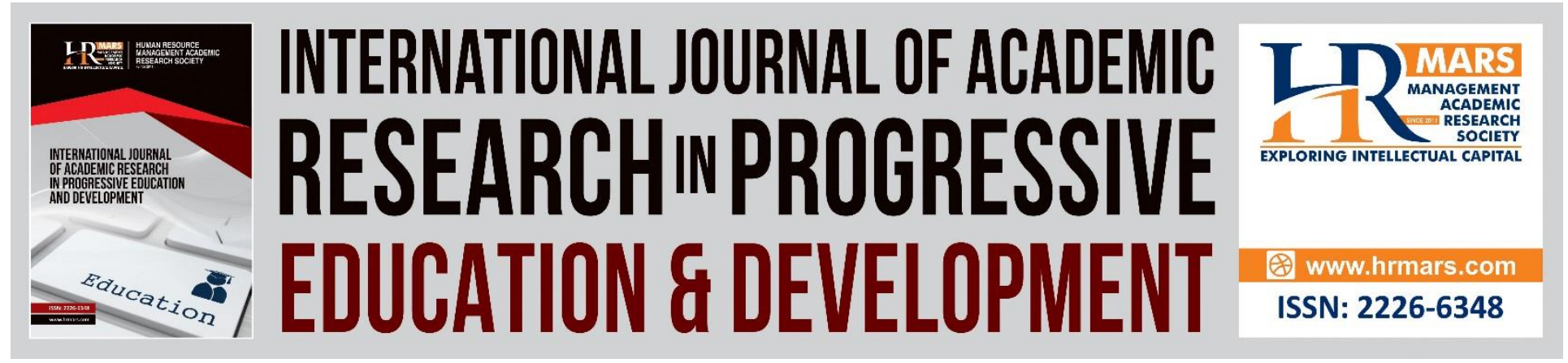

\title{
Teachers and Students Acceptance of an ESL Virtual Teaching-And-Learning in a Secondary School in Seremban
}

\author{
Wan Hasnizar Wan Hassan, Harwati Hashim \\ Faculty of Education, Universiti Kebangsaan Malaysia, Bangi, Malaysia
}

\begin{abstract}
No escapism to the ESL virtual teaching-and-learning for English-based teachers and students in this era. This research investigates the teachers' and students' acceptance of ESL virtual teachingand-learning in a secondary school in Seremban and the strengths and limitations. The importance of the study to acknowledge the gaps aimed at upskilling professionalism. This study incorporates descriptive statistical analysis and thematic analysis. Technology Acceptance Model (TAM) is integrated with this study to investigate teachers' and students' acceptance in ESL virtual teaching and learning. This case study incorporates both elements of quantitative and qualitative approaches in the research design. A sample of eight forms four teachers and thirty-three Form 4 students involved. Two types of questionnaires purposely for teachers and students distributed through Google Form are used to seek feedback on the ESL virtual learning. Interview employed by using semi-structured interviews to gather themes and five points Likert scale rate experiences. Data tabulated using tables and figures and in a form of frequency counts and percentages. Descriptive statistical analysis was used to interpret the response given by the respondents using Statistical Package for The Social Sciences (SPSS) and thematic analysis for qualitative data. The adaptation of the questionnaires, interviews, and SPSS as the instrument to elicit information on the acknowledgment of the acceptance of ESL virtual teaching and learning among the students and teachers. The findings of this study show that teachers' acceptance is higher and perceived the ESL virtual teaching-and-learning positively. On the other hand, students' acceptance and perception of ESL virtual teaching and learning is neutral.
\end{abstract}

Keywords: Acceptance, English as Second Language (ESL), Teaching-and-learning, ESL Virtual Learning

\section{Introduction}

Technology acceptance can be defined as a user's willingness to employ the technology for the tasks it is designed to support (Teo, 2011). The issues are mainly occurring when there is accepting or resisting the technology and the strengths and limitations in dealing with the ESL 
virtual teaching-and-learning. Computer systems cannot improve organizational performance if they aren't used. Unfortunately, resistance to end-user systems by managers and professionals is a widespread problem. To better predict, explain, and increase user acceptance, we need to better understand why people accept or reject computers Davis, Bagozzi, Warshaw(1989) Most of the problems are assembled with insufficient data storage, internet connection, time constrain in preparation of the materials and users' beliefs and attitudes not left behind. However, not everyone is facing the same problems. Lack of knowledge on the operation of ESL virtual learning and the effectiveness of materials shared and teaching should be taken into consideration. Therefore, teachers' and students' acceptance of the ESL virtual teaching-and-learning addressed for the betterment of the researcher, educator, or for future reference to upskilling the professionalism.

There are three research questions identified in this research: What are teachers' and students' levels of acceptance on the implementation of the ESL virtual teaching-and-learning? and How students and teachers perceive the strength and limitations of ESL virtual teaching and learning? The objectives of the research are to investigate teachers' and students' acceptance towards the implementation of virtual teaching and learning and to explore how teachers and students perceive the strengths and limitations of ESL.

As related to past studies Some students learned in different ways and some of them could adopt and adapt to the situation immediately but somehow couldn't. The way students learn depends on what the students can do and what the adjoining could stretch for them. The ESL Virtual teaching-and-learning has gauged impacts to students and teachers to learn to get used with the technology and at the same time to adjust as parallel to the current situation.

ICT has given a lot of assistance to advance teachers' pedagogical approaches. As Basri, Hashim, Yunus (2019) stated that every moment our education strategies have been evolving with the advent of new technology that simplifies teachers' workload in preparing materials and aids students engaged in their learning. Thus, teaching the English language virtually in the ESL virtual teaching-and-learning indifferent to face-to-face or real-life situations. Therefore, teachers responsible to adapt and adapt to the needs.

\section{Literature Review \\ Related Past Studies}

In Malaysia, it could be seen that the policymakers have done the initiative with the courseware, software, and recently the 1BestariNet project with inculcating the Frog virtual learning environment (FROG-VLE) in schools (Ministry of Education, 2012). 1BestariNet is a venture directed by the Ministry of Education (MOE), to deliver admittance to virtual learning platform known as the FROG-VLE and fast connectivity by June 2014 to all its 10,000 schools in Malaysia Hajar, Hanani \& Rafiza (2018) it is undeniable of the implementation of the virtual teaching-andlearning among teachers rooted quite some time. There are several studies conducted by a few researchers aligned with this topic as well. Dawadi, Cook, \& Schmitter-Edgecombe, July 2016 in their study claimed that promoting home technology benefits clinicians in performing their duties. As in ESL context, engaging English language skills is undisputable Maslawati, Naiman \& Harwati (2018) claimed that pupils gained several benefits, which include: having enjoyable and 
attentive lessons through the interactive features of Google+, as well as engaging themselves in an active and interesting lesson. The participants felt that they were having a sense of purpose, thus becoming more engaged in the writing tasks. As for interaction, the participants were interacting more confidently in Google+ writing classes compared to conventional writing lessons. As for the grammar aspect, gamified learning is known as Socrative, PowerPoint Challenge Game, and Kahoot resulted that gamified learning is effective in teaching grammar to ESL learners introduced by Harwati, Karmila, Melor (2019) opened various ways to explore the target language. The main contribution of the study is problems are acknowledged.

Technology Acceptance Model (TAM)

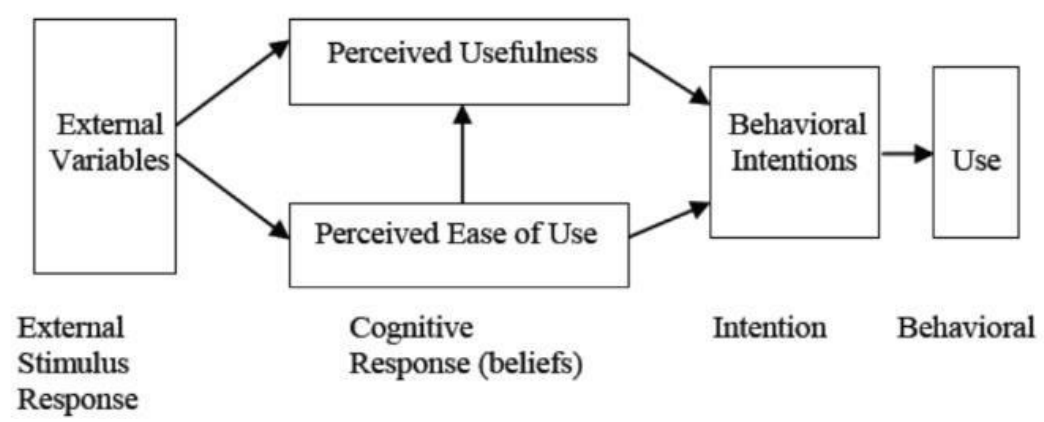

Figure 1: Technology Acceptance Model

(Adopted from Heather Holden \& Rada, 2014)

The framework for this research study was adapted from the Technology Acceptance Model (TAM) by Davis (1989). The Technology Acceptance Model (TAM) represents how users come to accept and use a given technology and can be applied to teachers' use of educational technologies Heather Holden \& Roy Rada (2014) In the modern era where technology cannot be neglected and there is a need for teachers to be equipped with the internet skills. The ESL virtual and face-to-face teaching-and-learning are two different ways and be perceived differently by different parties. For this reason, this study attempts to examine whether TAM is a valid model to predict the use of technology among pre-service teachers Timothy et al (2009). To understand how technology acceptance and support materials affect (perceived and actual) task performance. Meng et al (2010) claimed that due to the ubiquity of the World Wide Web, an online learning community allows learners to access up-to-date data through the Internet at anytime, anywhere

(WWW). 


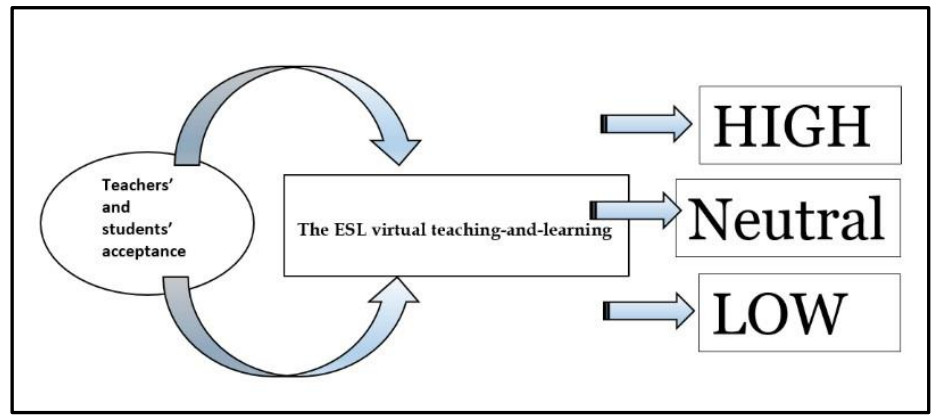

Figure 2: The Conceptual Framework of the study

Figure 2 depicts the study framework which is a theoretical framework on the structure that holds or supports the study. It provides the background of the study to justify the outcomes.

\section{Behaviorism}

This study underpinned the behaviorism theory. The theory of behaviorism concentrates on the study of overt behaviors that can be observed and measured (Good \& Brophy, 1990). The changes in behavior as a result of experience. Then developed into a flow of learning which influenced the direction of digesting and practicing. The behaviouristic theory was pioneered by Thorndike (1913); Pavlov (1927); and also Skiner (1974) assumes that learning is an observable behavior caused by an external stimulus. Thus, learning is transformed shown from seen behavior not from what is in the mind. Behaviourism was introduced by Ivan Pavlov and developed by Thorndike and Skinner, who argue that learning is related to behavior change, performed on animals such as rats, cats, and birds in the laboratory. They concentrate on a test of the relationship between 'stimulus' and 'response' that results in change behavior. In general, behaviorist theory states that teaching and learning will influence all student actions and behaviors whether good or otherwise. The theory also explains that student behavior can be observed, controlled, and predicted.

ESL Virtual Teaching-and-Learning

ESL virtual teaching-and-learning conducted in various skills taught. ESL teachers and students in a virtual classroom acquire language knowledge and skills by interacting with the online tutor, studying movies, texts, pictures, and accomplishing various home assignments. Focused skills implemented in the ESL virtual teaching-and-learning. According to (Annamalai, 2018) the increasing prevalence of digital media has allowed educationalists and practitioners to assimilate new technologies while designing diverse pedagogies in English language learning. She also claimed that online interactions seem to be an important feature in the use of technology as it complements teacher-fronted interactions by providing a context of practice. The learning skills taught in the ESL virtual teaching-and learning include Speaking, Writing, Listening, Speaking skills, Literature in Action, and Language Awareness. By using multimedia technology, educators can use a variety of mediums to convey knowledge, such as through simple images, audio, and visual animations among others, which helps to deliver information across the boundary of time and space. This will make the learning process more interesting for the students thus captivating their interests Afif, Harwati, \& Melor (2019) 


\section{Methodology}

This study employed a combination of two approaches Quantitative and Qualitative. A problem that cannot be fully addressed by one of the two approaches alone. It would be rather for the researcher and betterment in understanding and appreciate the problem if involved the two characteristics of the two approaches. There were eight teachers and thirty-three of form four students from SMK Seri Pagi who took part in this study. The data collection qualitative started with a questionnaire to explore the teachers' and students' levels of acceptance and perception of the ESL teaching-and-learning. Then developed an interview with the seven teachers to explore the findings. The data for the qualitative and quantitative were collected separately. In short, from the result of the interview, the researcher proceeded with the two questionnaires for both teachers and students and analyzed the data separately. For the final stage, the data has been mixed.

\section{Sampling}

A pilot survey focus group was interviewed to eight forms four teachers teaching form 4 to explore their level of acceptance evaluated. For the final stage, questionnaires were given to a larger group of thirty-three Form 4 students.

\section{The Instruments}

Two types of questionnaires purposely for both teachers and students distributed through Google Forms are used to investigate the level of teachers' and students' acceptance of ESL virtual learning. Semi-stretched interviews used in this study to gather the themes and a 5 points Likert scale to quantitatively rate the acceptance levels contributed to the increased chances of the findings. The interviews helped to explore more on the research problems with open-ended questions so in-depth information collected when teachers shared their personal story and anecdotes and experience when dealing with the ESL virtual teaching-and-learning.

\section{Results}

The findings of this study presented in the form of tables and figures. There are two types of questionnaires. The first questionnaire purposely both for teachers and students to answer. An interview was used to explore more information. For teachers, the questionnaire is divided into four sections: i) The aspect of teaching strategies, ii) Aids of teaching iii) The implementation of ESL virtual teaching sessions iv) demographic. For students, the questionnaire is divided into fivequestion with five sections: i) Parents' information ii) gender iii) Pt3 results from iv) Students' response v) Students' attitudes \& interest of the ESL virtual teaching-and-learning 
INTERNATIONAL JOURNAL OF ACADEMIC RESEARCH IN PROGRESSIVE EDUCATION AND DEVELOPMENT

Vol. 10, No. 2, 2021, E-ISSN: 2226-6348 @ 2021 HRMARS

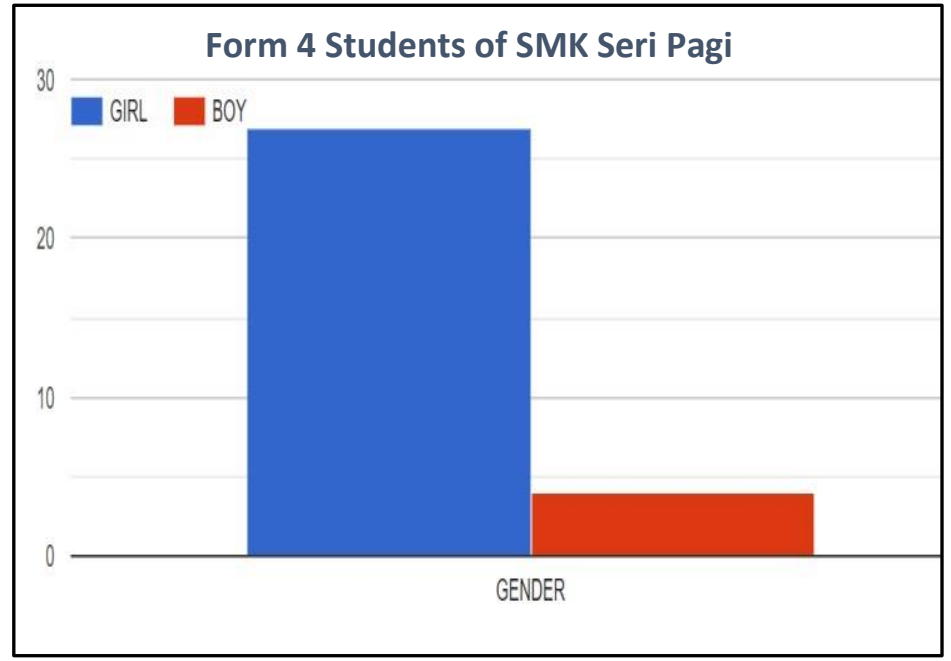

Figure 3: Students' gender

Figure 3 illustrates on students' gender of SMK Seri Pagi

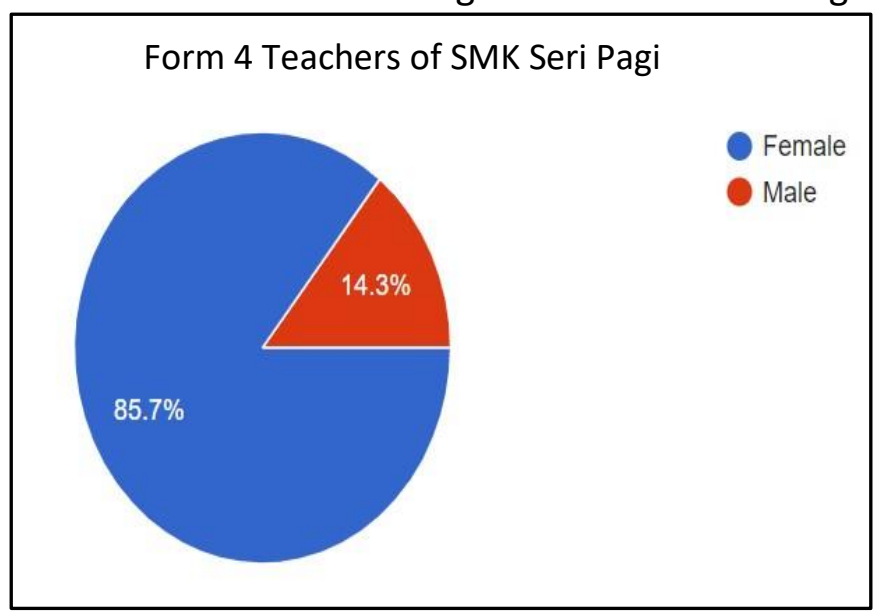

Figure 4: Teachers' gender

Figure 4 represents teachers' gender of SMK Seri Pagi.

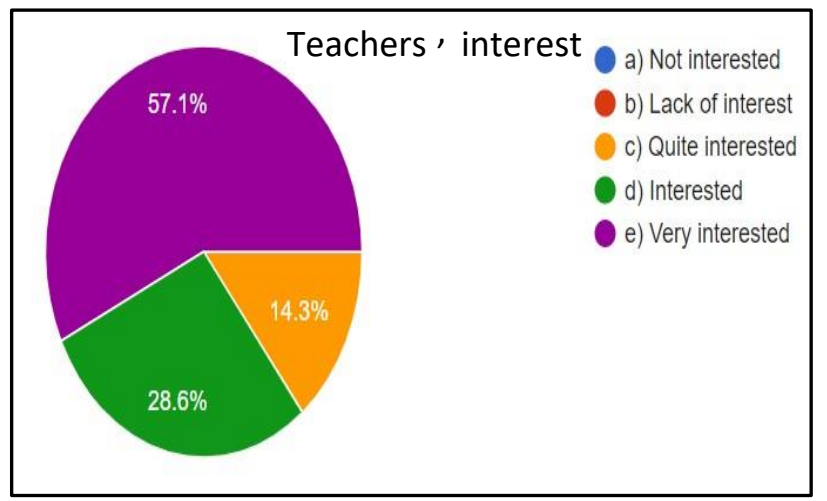

Figure 5: Teachers' interest 
INTERNATIONAL JOURNAL OF ACADEMIC RESEARCH IN PROGRESSIVE EDUCATION AND

DEVELOPMENT

Vol. 10, No. 2, 2021, E-ISSN: 2226-6348 @ 2021 HRMARS

Figure 5 depicts teachers' interest in an ESL virtual teaching-and-learning.

The following table depicts the frequency and percentage of teachers' practices.

PART 1: TEACHER TEACHING PRACTICES. Teachers' Perceptions of English Language Curriculum Implementation and Teaching

\begin{tabular}{|c|c|c|c|c|c|}
\hline \multirow[b]{2}{*}{ A. Teaching Materials } & $\begin{array}{l}(1) \\
\text { Strongly } \\
\text { disagree }\end{array}$ & (2) & $\begin{array}{c}\text { (3) } \\
\text { Neutral }\end{array}$ & $\begin{array}{l}\text { (4) } \\
\text { Agree }\end{array}$ & $\begin{array}{l}\text { (5) } \\
\text { Strongly } \\
\text { agree }\end{array}$ \\
\hline & \multicolumn{5}{|c|}{ Frequency (Percentage) } \\
\hline $\begin{array}{l}\text { 1) I use teaching materials that interest } \\
\text { students such as videos, PowerPoint } \\
\text { presentations, infographics, animations, } \\
\text { and others to attract students during online } \\
\text { learning }\end{array}$ & $1(12.5 \%)$ & $0(0 \%)$ & $2(25 \%)$ & $3(37.5 \%)$ & $1(12.5 \%)$ \\
\hline $\begin{array}{l}\text { 2) Instructions given to my students are simple } \\
\text { and easy to understand }\end{array}$ & $0(0 \%)$ & $0(0 \%)$ & $0(0 \%)$ & $5(62.5 \%)$ & $1(12.5 \%)$ \\
\hline $\begin{array}{l}\text { 3) The lessons taught through online learning } \\
\text { are easy to understand }\end{array}$ & $0(0 \%)$ & $1(12.5 \%)$ & $2(25 \%)$ & $3(37.5 \%)$ & $1(12.5 \%)$ \\
\hline $\begin{array}{l}\text { The syllabus is suitable and convenient for } \\
\text { 4) students }\end{array}$ & $0(0 \%)$ & $0(0 \%)$ & $1(12.5 \%)$ & $5(62.5 \%)$ & $1(12.5 \%)$ \\
\hline $\begin{array}{l}\text { 5. The goals of the English language contained in } \\
\text { the syllabus of the lesson are unclear }\end{array}$ & $0(0 \%)$ & $3(37.5 \%)$ & $2(25 \%)$ & $1(12.5 \%)$ & $1(12.5 \%)$ \\
\hline 6. The objectives of the lessons are clear & $0(0 \%)$ & $0(0 \%)$ & $0(0 \%)$ & $5(62.5 \%)$ & $0(0 \%)$ \\
\hline $\begin{array}{l}\text { 7. The curriculum specification is not very } \\
\text { helpful }\end{array}$ & $1(12.5 \%)$ & $4(50 \%)$ & $1(12.5 \%)$ & $0(0 \%)$ & $1(12.5 \%)$ \\
\hline 8. Activities given to students are relevant & $0(0 \%)$ & $0(0 \%)$ & $1(12.5 \%)$ & $4(50 \%)$ & $3(37.5 \%)$ \\
\hline $\begin{array}{l}\text { 9. Time frame is suitable and convenient to } \\
\text { students }\end{array}$ & $0(0 \%)$ & $0(0 \%)$ & $1(12.5 \%)$ & $4(50 \%)$ & $2(25 \%)$ \\
\hline $\begin{array}{l}\text { 10. Supervision while completing task given is } \\
\text { difficult }\end{array}$ & $1(12.5 \%)$ & $1(12.5 \%)$ & $3(37.5 \%)$ & $1(12.5 \%)$ & $1(12.5 \%)$ \\
\hline \multirow[b]{2}{*}{ B. Knowledge of English teaching methods } & \begin{tabular}{|c|} 
(1) \\
Strongly \\
disagree
\end{tabular} & $\begin{array}{l}\text { (2) } \\
\text { Disagree }\end{array}$ & $\begin{array}{c}\text { (3) } \\
\text { Neutral }\end{array}$ & $\begin{array}{l}\text { (4) } \\
\text { Agree }\end{array}$ & $\begin{array}{l}\text { (5) } \\
\text { Strongly } \\
\text { agree }\end{array}$ \\
\hline & \multicolumn{5}{|c|}{ Frequency (Percentage) } \\
\hline $\begin{array}{l}\text { 1. Emphasis on a teaching method is an } \\
\text { appropriate and effective ways }\end{array}$ & $0(0 \%)$ & $0(0 \%)$ & $3(37.5 \%)$ & $3(37.5 \%)$ & $1(12.5 \%)$ \\
\hline
\end{tabular}


INTERNATIONAL JOURNAL OF ACADEMIC RESEARCH IN PROGRESSIVE EDUCATION AND

DEVELOPMENT

Vol. 10, No. 2, 2021, E-ISSN: 2226-6348 @ 2021 HRMARS

\begin{tabular}{|l|l|l|l|l|l|}
\hline $\begin{array}{l}\text { 2. Diversifying teaching methods can help } \\
\text { students to understand the contents of the } \\
\text { lessons }\end{array}$ & $1(12.5 \%)$ & $0(0 \%)$ & $2(25 \%)$ & $2(25 \%)$ & $2(25 \%)$ \\
\hline $\begin{array}{l}\text { 3. Choosing the appropriate teaching method } \\
\text { can meet individual learning needs }\end{array}$ & $1(12.5 \%)$ & $0(0 \%)$ & $1(12.5 \%)$ & $3(37.5 \%)$ & $2(25 \%)$ \\
\hline $\begin{array}{l}\text { 4. Choosing the appropriate teaching method is } \\
\text { also possible meet the needs of group learning }\end{array}$ & $1(12.5 \%)$ & $0(0 \%)$ & $1(12.5 \%)$ & $3(37.5 \%)$ & $2(25 \%)$ \\
\hline $\begin{array}{l}\text { 5. The use of appropriate teaching methods can } \\
\text { stimulate and maintain students attention }\end{array}$ & $1(12.5 \%)$ & $0(0 \%)$ & $1(12.5 \%)$ & $3(37.5 \%)$ & $2(25 \%)$ \\
\hline $\begin{array}{l}\text { 6. The use of appropriate teaching methods can } \\
\text { improve students achievement }\end{array}$ & $1(12.5 \%)$ & $0(0 \%)$ & $1(12.5 \%)$ & $\mathbf{3 ( 3 7 . 5 \% )}$ & $2(25 \%)$ \\
\hline $\begin{array}{l}\text { 7. The success of teaching and learning is } \\
\text { depending on the discretion of the teacher }\end{array}$ & $1(12.5 \%)$ & $0(0 \%)$ & $1(12.5 \%)$ & $\mathbf{3 ( 3 7 . 5 \% )}$ & $\mathbf{1 ( 1 2 . 5 \% )}$ \\
\hline $\begin{array}{l}\text { 8. I am equipped with wide knowledge of } \\
\text { teaching the English language }\end{array}$ & $1(12.5 \%)$ & $0(0 \%)$ & $2(25 \%)$ & $\mathbf{3 ( 3 7 . 5 \% )}$ & $2(25 \%)$ \\
\hline
\end{tabular}

Table 1: Likert Scale Specifications of Teachers' Teaching Practices

Based on the result tabulated in Table 1, the most common practices applied by the teachers are "Instructions given to my students are simple and easy to understand", "The syllabus is suitable and convenient for students", "The objectives of the lessons are clear", "The curriculum specification is not very helpful". All practices are reported at the second-highest Likert scale, 4 (Agree) except for "The curriculum specification is not very helpful" reported at 2 (Disagree). The practices were recorded at 5 (62.5\%) and 4 (50\%).

This is followed by Knowledge of English language teaching methods are Agree [Likert scale $=4$ ] used most by the respondents. 
INTERNATIONAL JOURNAL OF ACADEMIC RESEARCH IN PROGRESSIVE EDUCATION AND DEVELOPMENT

Vol. 10, No. 2, 2021, E-ISSN: 2226-6348 @ 2021 HRMARS

\begin{tabular}{|c|c|c|c|c|c|}
\hline \multirow[b]{2}{*}{ Aids of teaching } & $\begin{array}{c}\text { (1) } \\
\text { Strongly } \\
\text { disagree }\end{array}$ & $\begin{array}{l}\text { (2) } \\
\text { Disagree }\end{array}$ & $\begin{array}{c}\text { (3) } \\
\text { Neutral }\end{array}$ & $\begin{array}{l}\text { (4) } \\
\text { Agree }\end{array}$ & $\begin{array}{l}\text { (5) } \\
\text { Strongly } \\
\text { agree }\end{array}$ \\
\hline & \multicolumn{5}{|c|}{ Frequency (Percentage) } \\
\hline 1. Jamboard & $5(62.5 \%)$ & $0(0 \%)$ & $1(12.5 \%)$ & $1(12.5 \%)$ & $0(0 \%)$ \\
\hline 2. Animation/Video & $0(0 \%)$ & $1(12.5 \%)$ & $3(37.5 \%)$ & $2(25 \%)$ & $0(0 \%)$ \\
\hline 3. Choogle Application & $4(50 \%)$ & $0(0 \%)$ & $0(0 \%)$ & $1(12.5 \%)$ & $1(12.5 \%)$ \\
\hline 4. Google Drive & $3(37.5 \%)$ & $0(0 \%)$ & $2(25 \%)$ & $1(12.5 \%)$ & $0(0 \%)$ \\
\hline 5. Canva & $5(62.5 \%)$ & $0(0 \%)$ & $1(12.5 \%)$ & $1(12.5 \%)$ & $0(0 \%)$ \\
\hline 6. Virtual white-board & $2(25 \%)$ & $0(0 \%)$ & $1(12.5 \%)$ & $2(25 \%)$ & $2(25 \%)$ \\
\hline 7. Lingua House & $6(75 \%)$ & $0(0 \%)$ & $0(0 \%)$ & $1(12.5 \%)$ & $0(0 \%)$ \\
\hline 8. Quizziz & $1(12.5 \%)$ & $0(0 \%)$ & $4(50 \%)$ & $1(12.5 \%)$ & $1(12.5 \%)$ \\
\hline 9. Kahoot & $4(50 \%)$ & $0(0 \%)$ & $1(12.5 \%)$ & $1(12.5 \%)$ & $0(0 \%)$ \\
\hline 10.Google Meet & $1(12.5 \%)$ & $1(12.5 \%)$ & $1(12.5 \%)$ & $2(25 \%)$ & $2(25 \%)$ \\
\hline 11. Zoom & $4(50 \%)$ & $0(0 \%)$ & $1(12.5 \%)$ & $1(12.5 \%)$ & $1(12.5 \%)$ \\
\hline 12. Microsoft Team & $3(37.5 \%)$ & $0(0 \%)$ & $4(50 \%)$ & $0(0 \%)$ & $0(0 \%)$ \\
\hline 13. Google Form & $1(12.5 \%)$ & $1(12.5 \%)$ & $1(12.5 \%)$ & $2(25 \%)$ & $2(25 \%)$ \\
\hline 14. Google Drive & $3(37.5 \%)$ & $0(0 \%)$ & $1(12.5 \%)$ & $2(25 \%)$ & $1(12.5 \%)$ \\
\hline 15. Google Classroom & $2(25 \%)$ & $0(0 \%)$ & $2(25 \%)$ & $1(12.5 \%)$ & $2(25 \%)$ \\
\hline
\end{tabular}

Table 2: Likert scale of Teachers' Aids of teaching 
INTERNATIONAL JOURNAL OF ACADEMIC RESEARCH IN PROGRESSIVE EDUCATION AND DEVELOPMENT

Vol. 10, No. 2, 2021, E-ISSN: 2226-6348 @ 2021 HRMARS

Based on Table 2, the most useable teaching aids is Microsoft Teams recorded 4 (50\%).

\begin{tabular}{|c|c|c|c|c|c|}
\hline & $\begin{array}{l}\text { (1) } \\
\text { Strongly } \\
\text { disagree }\end{array}$ & $\begin{array}{l}\text { (2) } \\
\text { Disagree }\end{array}$ & $\begin{array}{c}\text { (3) } \\
\text { Neutral }\end{array}$ & $\begin{array}{l}\text { (4) } \\
\text { Agree }\end{array}$ & $\begin{array}{c}\text { (5) } \\
\text { Strongly } \\
\text { agree }\end{array}$ \\
\hline Pupils' self-controlled learning at home & \multicolumn{5}{|c|}{ Frequency (Percentage) } \\
\hline $\begin{array}{l}\text { 1. My parents are good at delivering } \\
\text { lessons at home throughout my } \\
\text { online learning }\end{array}$ & $2(6.45 \%)$ & $1(3.23 \%)$ & $18(58.1 \%)$ & $8(25.8 \%)$ & $2(6.45 \%)$ \\
\hline $\begin{array}{l}\text { 2. I prefer to be taught by my teachers } \\
\text { rather than parents }\end{array}$ & $1(3.23 \%)$ & $1(3.23 \%)$ & $13(41.9 \%)$ & $7(22.6 \%)$ & $12(38.7 \%)$ \\
\hline $\begin{array}{l}\text { 3. I prefer to be taught by my parents } \\
\text { rather than my teacher }\end{array}$ & $1(3.23 \%)$ & $5(6.5 \%)$ & $24(77.4 \%)$ & $2(6.45 \%)$ & $1(3.23 \%)$ \\
\hline 4. I can write very well in English & $1(3.23 \%)$ & $5(6.5 \%)$ & $9(29.0 \%)$ & $12(38.7 \%)$ & $5(6.5 \%)$ \\
\hline $\begin{array}{l}\text { 5. I can read comprehensively in } \\
\text { English }\end{array}$ & $1(3.23 \%)$ & $0(0 \%)$ & $9(29.0 \%)$ & $14(45.2 \%)$ & $7(22.6 \%)$ \\
\hline 6. I can speak fluently in English & $1(3.23 \%)$ & $3(9.68 \%)$ & $9(29.0 \%)$ & $13(41.9 \%)$ & $5(6.5 \%)$ \\
\hline 7. I can listen attentively English & $1(3.23 \%)$ & $7(22.6 \%)$ & $16(51.6 \%)$ & $7(22.6 \%)$ & $0(0 \%)$ \\
\hline $\begin{array}{l}\text { 8. I can understand what my teacher } \\
\text { has taught me }\end{array}$ & $1(3.23 \%)$ & $0(0 \%)$ & $8(25.8 \%)$ & $12(38.7 \%)$ & $10(32.3 \%)$ \\
\hline $\begin{array}{l}\text { 9. I like face-to-face English language } \\
\text { lessons }\end{array}$ & $1(3.23 \%)$ & $1(3.23 \%)$ & $3(9.68 \%)$ & $15(48.4 \%)$ & $11(35.5 \%)$ \\
\hline $\begin{array}{l}\text { 10. I like online English language } \\
\text { lessons }\end{array}$ & $2(6.45 \%)$ & $5(6.5 \%)$ & $13(41.9 \%)$ & $7(22.6 \%)$ & $4(12.9 \%)$ \\
\hline
\end{tabular}

Table 3: Pupils' self-controlled learning

Table 3 reported the most common pupils' self-controlled learning at home is "I prefer to be taught by my parents rather than my teacher", followed by "My parents are good in delivering lessons at home throughout my online learning" and "I can listen attentively in English". There are 24(77.4\%), 18(58.1\%) and 16 (51.6\%) 
INTERNATIONAL JOURNAL OF ACADEMIC RESEARCH IN PROGRESSIVE EDUCATION AND DEVELOPMENT

Vol. 10, No. 2, 2021, E-ISSN: $2226-6348$ @ 2021 HRMARS

\begin{tabular}{|c|c|c|c|c|c|}
\hline \multirow{2}{*}{$\begin{array}{l}\text { Pupils' Attitudes and Interests of an ESL } \\
\text { virtual teaching-and-learning }\end{array}$} & $\begin{array}{c}\text { (1) } \\
\text { Strongly } \\
\text { disagree }\end{array}$ & $\begin{array}{l}\text { (2) } \\
\text { Disagree }\end{array}$ & $\begin{array}{c}\text { (3) } \\
\text { Neutral }\end{array}$ & $\begin{array}{l}\text { (4) } \\
\text { Agree }\end{array}$ & $\begin{array}{l}\text { (5) } \\
\text { Strongly } \\
\text { agree }\end{array}$ \\
\hline & \multicolumn{5}{|c|}{ Frequency (Percentage) } \\
\hline 1.I am very interested in English subject & $0(0 \%)$ & $0(0 \%)$ & $11(35.5 \%)$ & $12(38.7 \%)$ & $8(25.8 \%)$ \\
\hline $\begin{array}{l}\text { 2. Learning English language encourages } \\
\text { me to think }\end{array}$ & $0(0 \%)$ & $0(0 \%)$ & $7(22.6 \%)$ & $15(48.4 \%)$ & $8(25.8 \%)$ \\
\hline $\begin{array}{l}\text { 3.Learning English language gives impacts } \\
\text { in my life }\end{array}$ & $0(0 \%)$ & $0(0 \%)$ & $9(29.0 \%)$ & $13(41.9 \%)$ & $9(29.0 \%)$ \\
\hline $\begin{array}{l}\text { 4.The use of mind maps, videos, power } \\
\text { point presentation, graphic information } \\
\text { etc. attracted my interest in learning } \\
\text { English language }\end{array}$ & $0(0 \%)$ & $0(0 \%)$ & $7(22.6 \%)$ & $12(38.7 \%)$ & $9(29.0 \%)$ \\
\hline $\begin{array}{l}\text { 5.My English subject teacher is able to } \\
\text { liven up the learning environment } \\
\text { through this method of online learning }\end{array}$ & $0(0 \%)$ & $0(0 \%)$ & $14(45.2 \%)$ & $8(25.8 \%)$ & $8(25.8 \%)$ \\
\hline
\end{tabular}

Table 4: Pupils' Attitudes and Interest of an ESL virtual teaching-and-learning

Additionally, results tabulated on pupils' attitudes and interest of an ESL virtual teaching-and learning are "Learning the English language encourages me to think", "My English subject teacher can liven up the learning environment through this method of online learning" and

"Learning the English language gives an impact on my life". There are 15 (48.4\%), 14(45.2\%) and $13(41.9 \%)$

Validity and Reliability

\begin{tabular}{ll}
\hline Reliability Statistics & \\
\hline Cronbach's Alpha & N of Items \\
\hline .949 & 27 \\
\hline
\end{tabular}

Table 5: Reliability Statistics 
Vol. 10, No. 2, 2021, E-ISSN: 2226-6348 @ 2021 HRMARS

Table 5 shows the reliability statistics, a pilot study was carried out to determine the reliability of the questionnaire and the Cronbach's Alpha value of $0.949 \geq 0.6$ showed that the instrument used is reliable to investigate teacher's and students' acceptance.

\begin{tabular}{|l|l|l|l|}
\hline $\begin{array}{l}\text { Descriptive } \\
\text { Statistics }\end{array}$ & Mean & $\begin{array}{l}\text { Std. } \\
\text { Deviation }\end{array}$ & N \\
\cline { 1 - 3 } $\begin{array}{l}\text { Aids of teaching } \\
\begin{array}{l}\text { Teachers } \\
\text { practices }\end{array}\end{array}$ & 1.5000 & 1.30931 & 8 \\
\hline
\end{tabular}

Table 6: Descriptive statistics of teachers' two variables

Table 6 shows Descriptive statistics of teachers' two variables are Aids of teaching and Teacher practices. The mean score for Aids of teaching is 1.5 which is very low between $1.00-$

1.79. Additionally, the mean score for teachers' practices is 3.0 which is a medium between 2.60 -3.39 .

\begin{tabular}{|ll|l|l|}
\hline Correlations & & $\begin{array}{l}\text { Teaching } \\
\text { Practices }\end{array}$ & $\begin{array}{l}\text { Aids } \\
\text { teaching }\end{array}$ \\
\cline { 1 - 2 } & & Pearson & \\
Teaching & Correlation & & \\
Practices & Sig. (2-tailed) & & \\
& $\mathrm{N}$ & 8 & \\
& Pearson & $.721^{*}$ & 1 \\
& Correlation & .043 & \\
Aids of teaching & Sig. (2-tailed) & 8 & 8 \\
\hline
\end{tabular}

*. Correlation is significant at the 0.05 level (2-tailed).

Table 7: Correlations of Teachers' two variables

For table 7, depicts the Correlations of teachers' two variables. Data shows that there is a very strong and significant relationship between teaching practices and aids of teaching $(r=0.721, p-$ value $=0.043$ ) 
Vol. 10, No. 2, 2021, E-ISSN: $2226-6348$ @ 2021 HRMARS

\begin{tabular}{|l|l|l|l|}
\hline Descriptive Statistics & Mean & $\begin{array}{l}\text { Std. } \\
\text { Deviation }\end{array}$ & N N \\
\hline $\begin{array}{l}\text { Home surveillance } \\
\text { Students' attitude } \quad \& \\
\text { interest }\end{array}$ & $\begin{array}{l}3.9394 \\
3.5455\end{array}$ & 1.37138 & 33 \\
& & 3327 & 33 \\
\hline
\end{tabular}

Table 8: Descriptive analysis of students' two variables

Table 8 shows Descriptive statistics of home surveillance and students' attitude \& interest. The mean score for home surveillance is 2.9 which is a medium between $2.60-3.39$. Additionally, the mean score for students' attitude $\&$ interest is 3.5 which is high between $3.40-4.19$.

\begin{tabular}{|c|c|c|c|c|}
\hline \multicolumn{2}{|l|}{ Correlations } & \multirow{2}{*}{$\begin{array}{l}\text { Home } \\
\text { surveillance }\end{array}$} & \multirow{2}{*}{$\begin{array}{l}\text { Students' } \\
\text { attitude } \\
\text { interest } \\
700^{* *}\end{array}$} & $\&$ \\
\hline \multirow{4}{*}{ Home survailance } & $\begin{array}{l}\text { Pearson } \\
\text { Correlation }\end{array}$ & & & \\
\hline & Sig. (2-tailed) & & .000 & \\
\hline & $N$ & 33 & & \\
\hline & Pearson & $.700^{* *}$ & & 33 \\
\hline \multirow[t]{2}{*}{$\begin{array}{l}\text { Students' attitude } \\
\text { interest }\end{array}$} & $\begin{array}{l}\& \begin{array}{l}\text { Correlation } \\
\text { Sig. (2-tailed) }\end{array}\end{array}$ & & & \\
\hline & $\mathrm{N}$ & 33 & 33 & \\
\hline
\end{tabular}

$* *$. Correlation is significant at the 0.01 level (2-tailed).

Table 9: Correlations of students' two variables

For table 9, depicts the Correlations of students' two variables. Data shows that there is moderate and significant relationship between home surveillance and students' attitude \& interest $(r=$ $0.700, p$-value $=0.000$ )

\begin{tabular}{|l|l|l|l|}
\hline Descriptive Statistics & Mean & $\begin{array}{l}\text { Std. } \\
\text { Deviation }\end{array}$ & N \\
\hline Teachers' reflection & 3.2500 & 1.66905 & 8 \\
Students' Attitudes \& & 3.7333 & 1.08066 & 30 \\
Interests & & & \\
\hline
\end{tabular}

Table 10: Descriptive statistics of teachers' and students' variables

Table 10 shows Descriptive statistics of teachers' reflection and students' attitude \& interest. The mean score for teachers' reflection is 3.25 which is a medium between $2.60-3.39$. 
INTERNATIONAL JOURNAL OF ACADEMIC RESEARCH IN PROGRESSIVE EDUCATION AND

DEVELOPMENT

Vol. 10, No. 2, 2021, E-ISSN: 2226-6348 @ 2021 HRMARS

Additionally, the mean score for students' attitude \& interest is 3.7 which is high between 3.40 -4.19 .

\begin{tabular}{|ll|l|l|}
\hline Correlations & & $\begin{array}{l}\text { Teachers' } \\
\text { reflection }\end{array}$ & $\begin{array}{l}\text { Students' } \\
\text { Attitudes \& } \\
\text { Interests } \\
978^{* *}\end{array}$ \\
\hline & $\begin{array}{l}\text { Pearson } \\
\text { Correlation }\end{array}$ & 1 & .000 \\
& Sig. (2-tailed) & & 8 \\
Teachers' reflection & $\mathrm{N}$ & 1 \\
& Pearson & $.978^{* *}$ & \\
Students' Attitudes \& & Correlation & & 30 \\
Interests & Sig. (2-tailed) & .000 & \\
& $\mathrm{~N}$ & 8 & \\
\hline
\end{tabular}

**. Correlation is significant at the 0.01 level (2-tailed).

Table 11: Correlations of teachers' and students' two variables

For table 9, depicts the Correlations between teachers' reflections and students' two variables. Data shows that there is a very high and significant relationship between teachers' reflection and students' attitude $\&$ interest $(r=0.700, p$-value $=0.000)$

\begin{tabular}{|c|c|}
\hline Mean score & Interpretation of mean score \\
\hline $1.00-1.79$ & Very low \\
\hline $1.80-2.59$ & Low \\
\hline $2.60-3.39$ & Medium \\
\hline $3.40-4.19$ & High \\
\hline $4.20-5.00$ & Very high \\
\hline \multicolumn{2}{|c|}{} \\
\hline \multicolumn{2}{|c|}{ (Source: Educational Planning and Research Division (EPRD), MOE, 2006) } \\
\hline
\end{tabular}

Figure 6: Table of the mean score (Adopted from Educational Planning and Research Division) 
Vol. 10, No. 2, 2021, E-ISSN: $2226-6348$ @ 2021 HRMARS

Figure 6 shows the mean score reference used.

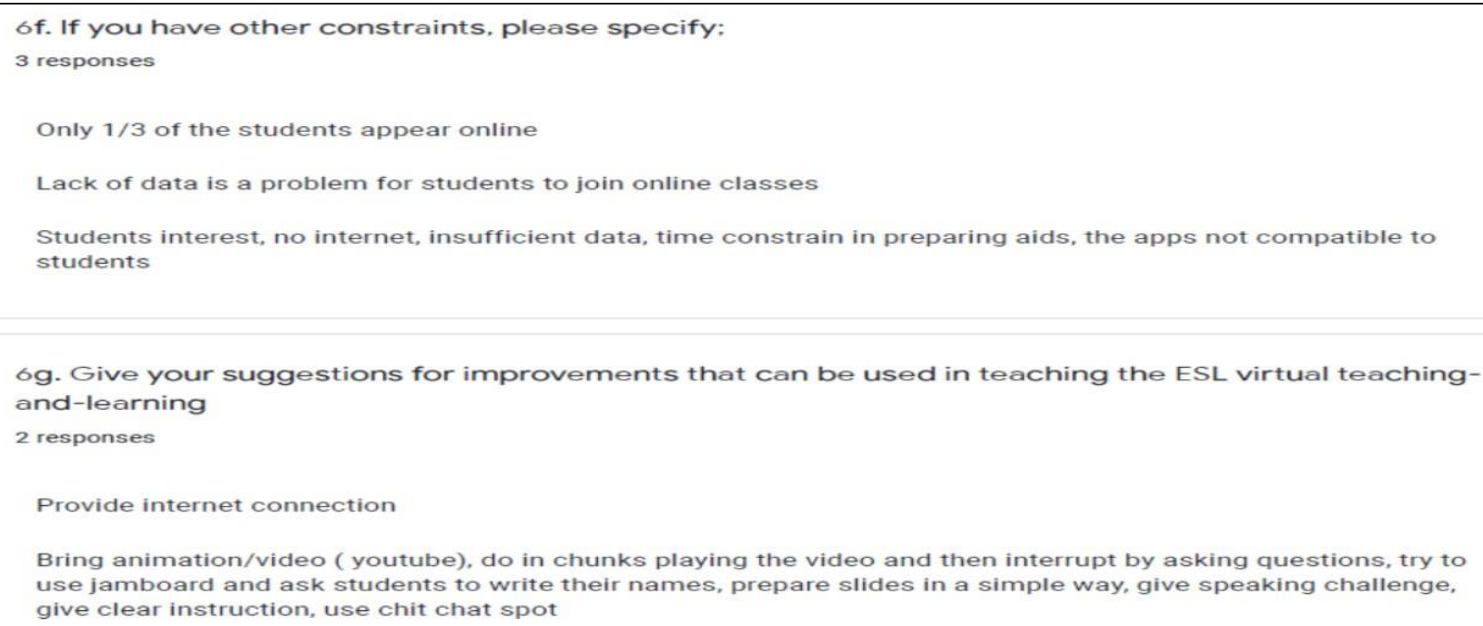

Figure 7: Teachers' response to constraints

Figure 7 shows teachers' responses to constraints that they have faced during the ESL virtual teaching-and-learning. The response depicts the problems faced such as poor attendance appear when online, lack of data problems, students' interest, insufficient data, time constrain in preparing the aids, and the application is not compatible with the students. There is also suggestion like providing the internet and bring animation/video like YouTube, do in chunks by playing the video then interrupt by asking questions, try to use jam board and ask students to write their names, simply prepare slides, give speaking challenge, give clear instruction and use chit chat spot.

\section{Discussion}

Teachers' acceptance of an ESL virtual teaching-and-learning

The research findings and analysis of this study showed that teachers have equipped with the skills and ever ready to conduct either face-to-face or virtual teaching-and-learning. Also, it depicts that teachers are very committed and professional with their careers. The use of aids in the ESL virtual teaching-and-learning portrays that teachers are very expert in the field. Thus, learners may also be engaged in at Jason, Nick \& Chris (2013) that might be helpful for teachers to implement in the lesson so that it might increase students' interest towards learning. The concepts of online teaching addressed in the 'best practices' literature are similar to those of face-to-face settings, based on the common emphasis on subject field knowledge, communication skills, and educational design skills Meredith, Richard, Erik \& Megan (2008). Teachers have to play their roles and need to find a solution that fits the needs of the learners in effectively carrying out the virtual lesson. Thus, the first research question about teachers' acceptance is addressed.

Students' acceptance of an ESL virtual teaching-and-learning

The research findings and analysis of this study showed that students' acceptance is neutral preferred to be taught by their parents at home. Based on the findings, students' attitudes and interests reflect on the neutral acceptance of the ESL virtual teaching and learning. Students 
prefer to be assisted by their parents at home. As C.Y. Dee \& Elizabeth (2017) claimed that it is fairly common to observe students assuming a passive role in the process of learning, waiting for their teachers to provide them with information and examination tips in schools. The ramification is students in this context become devout rote learners; memorizing facts to pass examinations and not for long-term knowledge or skills gain

Strengths, Limitations, and Recommendations

The findings of this study have provided that teachers' acceptance and perception of an ESL virtual teaching-and-learning is higher compared to students' acceptance is slightly neutral. What is expected is that it would be better if there is higher support from students and not only from teachers. Teachers are always ever ready and equipped for the teaching profession. There are other different types of possible interactive learning tools other than Microsoft teams, such as Blackboard, Edmodo, Google Classroom, and ClassDojo, and they have plenty of scopes to explore. Hybrid teaching and learning methods can be supported through the available tools through the techniques of learning management systems such as Docebo, Udemy, Skillshare, WizIQ, Adobe Captivate Prime, and SAP Litmos.

However, several considerations need to be taken into account to ensure successful online learning methods, such as the construction of environmental controls, the value of social engagement, efficient and effective training, access to full technical access, uniform requirements, unrestricted quality assurance, tolerance to existing and technological changes, intellectual property concerns, etc. Teachers need to incorporate equipment and methodology that can help enhance the quality of the learning process by providing the students with valuable information and the experiences they have carried out in the online learning system.

Also, teachers and school organizations performing online teaching and learning methods need to ensure that social networks are accurate and able to assess real academic success and ensure that there is no problem of unauthorized leakage of information by a managed security network. There is no doubt that many advantages are available by online learning methods. Online teaching makes it possible to introduce the learning process irrespective of the distance and number of participants browsing it. Students should also go through a continuous phase of learning as well as be able to more easily transfer information. As an alternative to education, facilities and resources for online discussions and teaching aids for content may also be provided.

The contribution of this study functions as a guideline especially to students, teachers, school staff and researchers throughout the country who would like to undergo further studies in the similar field. This study works on the theory of TAM framework that highlights the willingness of acceptance and resistance to the use of the internet in learning and teaching in cyberspace as well as the concept of Behaviourism that match with the attitude of users in accepting or rejecting the learning in cyberspace. To conclude, it is hoped that this article will give an insight for future studies for the betterment of the teachers' professionalism of the ESL virtual teaching-and-learning to adapt and adopt for the improvement. 
INTERNATIONAL JOURNAL OF ACADEMIC RESEARCH IN PROGRESSIVE EDUCATION AND

DEVELOPMENT

Vol. 10, No. 2, 2021, E-ISSN: 2226-6348 @ 2021 HRMARS

\section{References}

Abdulwahab, K., \& Dahalin, Z. (2010). A Conceptual Model of Unified Theory of Acceptance and Use of Technology. A Conceptual Model of Unified Theory of Acceptance and Use of Technology, Vol. 11, No. 4.

Annamalai, N. (2018). A Case Study of The Online Interactions. A Case Study of the Online Interactions, Volume 6 - Issue 1.

Basri, H., Hashim, H., \& Yunus, M. (2019). Using Google Apps as Learning Strategy to Enhance ESL Writing. Using Google Apps as Learning Strategy to Enhance ESL Writing.

Chavan, R. L., Pratibha \& Patankar, S. (n.d.). Constructivist Strategies for Minimization of Science Misconception Among. Constructivist Strategies for Minimization of Science Misconception Among, 7.

Chen, J., Zap, N., \& Dede, C. (2013). Using Virtual Environments to Motivate Students to Pursue STEM Careers: An Expectancy-Value Model. Using Virtual Environments to Motivate Students to Pursue STEM Careers: An Expectancy-Value Model, 15.

Davis, F. D., Bagozzi, R. P., \& Warshaw, P. R. (1989). User Acceptance of Computer Technology. User Acceptance of Computer Technology: A Comparison of Two Theoretical Models, 24.

Dee, C. Y., \& Anthony, E. (2017). Learner Autonomy in University English Classrooms. Teachers' Perceptions and Practices. Learner Autonomy in University English Classrooms: Teachers' Perceptions and Practices.

DiPietro, M., Ferdig, R. E., Black, E. W., \& Preston, M. (2008). Best practices in teaching K-12 online: Lessons learned from Michigan Virtual School teachers. Best practices in teaching K-12 online: Lessons learned from Michigan Virtual School teachers, Volume 7, Number 1.

Dillenbourg, P., Schneider, D., \& Synteta, P. (2007). Virtual Learning Environments. Virtual Learning Environments, 18.

Fishbein, M. (2012). Martin Fishbein's Legacy: The Reasoned Action Approach.

Hashim, H., Rafiq, M. K. R., \& Yunus, M. (2019.). Improving ESL Learners' Grammar with GamifiedLearning. Improving ESL Learners' Grammar with Gamified-Learning.

Halili, S. H., Rahman, N. H. A., \& Razak, R. A. (2018). Traditional versus virtual learning: How engaged are the students in learning English literature? Traditional versus virtual learning: How engaged are the students in learning English literature?

Holden, H., \& Rada, R. (2014). Understanding the Influence of Perceived Usability and Technology Self-Efficacy on Teachers' Technology Acceptance. Understanding the Influence of Perceived Usability and Technology Self-Efficacy on Teachers' Technology Acceptance.

Houwer, J. D., Holmes, D. B., \& Moors, A. (2013). What is learning? On the nature and merits of a functional definition of learning. What is learning? On the nature and merits of a functional definition of learning, 631 - 642.

Knutzen, K. B., \& Kennedy, D. (2012). Learning a Second Language in a Virtual Environment. Learning a Second Language in a Virtual Environment, 20.

Kanninen, E. (2009). Learning Styles and E-Learning. Learning Styles and E-Learning, 83.

Little, D. (n.d.). Learner autonomy: drawing together the threads of self-assessment, goalsetting, and reflection. Learner autonomy: drawing together the threads of self-assessment, goalsetting, and reflection, 3 . 
Meng, F. L., Chen, C., Suna, Y. S., DavidWible \& HwaKuod, C. (2010). Extending the TAM model to explore the factors that affect Intention to Use an Online Learning Community. Extending the TAM model to explore the factors that affect Intention to Use an Online Learning Community, 600-610.

Mohammad, M., Ghazali, N., \& Hashim, H. (2018). Secondary School Students' Perceptions on the Use of Google+ towards Improving ESL Writing Skills. Secondary School Students' Perceptions on the Use of Google+ towards Improving ESL Writing Skills.

Razali, M. A., Hashim, H., \& Yunus, M. (2019). Beyond ESL Classroom: The Use of MOOC in Enhancing ESL Reading Skills. Beyond ESL Classroom: The Use of MOOC in Enhancing ESL Reading Skills.

Teo, T. (2011). Technology Acceptance in Education Research And Issues. Netherlands: The Netherlands www.sensepublishers.com.

Teo, T., Lee, C. B., Chai, C. S., \& Wong, S. L. (2009). Assessing the intention to use technology among pre-service teachers in Singapore and Malaysia: A multigroup invariance analysis. Assessing the intention to use technology among pre-service teachers in Singapore and Malaysia: A multigroup invariance analysis, 10.

Väljataga, T., \& Fiedler, S. (2009). Supporting students to self-direct intentional learning projects with social. Supporting students to self-direct intentional learning projects with social, 5869.

Yunus, M., Osman, W. S., \& Ishak, N. M. (2011). Teacher-student relationship factor affecting motivation and academic achievement in ESL classroom. Teacher-student relationship factor affecting motivation and academic achievement in ESL classroom, 5. 